\title{
Nutritional role of protists in the diet of first stage larvae of the Dungeness crab Cancer magister
}

\author{
Stephen Sulkin*, Jason Lehto, Suzanne Strom, Debbie Hutchinson
}

Shannon Point Marine Center, 1900 Shannon Point Road, Anacortes, Washington 98221, USA

\begin{abstract}
Two naturally occurring dinoflagellates, the autotrophic Prorocentrum micans and the heterotrophic Noctiluca scintillans (non-bioluminescent), and the: green alga Dunaliella tertiolecta were tested as prey for the first zoeal stage of the brachyuran crab cancer magister under controlled laboratory conditions. Each dinoflagellate was tested alone and in combination with a suboptimal application of the nauplius of the brine shrimp Artemia sp., a diet of known value. When offered alone, both dinoflagellates delayed mortality as compared to an unfed control, but neither supported development to the second zoeal stage. When larvae were fed a cycle of $1 \mathrm{~d}$ of Artemia sp. nauplii, followed by $2 \mathrm{~d}$ of either dinoflagellate, survival to zoeal stage Il was significantly higher than for larvae fed $1 \mathrm{~d}$ of nauplii followed by $2 \mathrm{~d}$ unfed. Indeed, survival was equal to a control that had been fed nauplii continuously, although there was a significant delay in time to molt. Larvae fed $D$. tertiolecta in combinatıon with nauplii showed a reduction in survival as compared to the suboptimal nauplius diet alone and no difference in time to molt. All 3 protists were consumed and the 2 dinoflagellates contributed nutritionally. Given the susceptibility of newly hatched brachyuran larvae to starvation, their ability to prey upon protists may be significant, especially for C. magister, a species that hatches in the Puget Sound (WA, USA) region in winter, a time of very low primary productivity. Crab larvae that can consume protistan prey may serve as a link between the rich carbon sources of the microbial food web and metazoans.
\end{abstract}

KEY WORDS: Crab larvae - Nutrition - Protists · Dinoflagellates

\section{INTRODUCTION}

A large fraction of marine carbon fixation is carried out by colls less than $5 \mu \mathrm{m}$ in size, too small to be grazed effectively by most planktonic metazoans (Sherr \& Sherr 1991). Even in coastal waters, greater than $50 \%$ of total primary productivity can be attributed to these small algal cells (Throndsen 1979, Joint \& Pomeroy 1983, P. Boyd \& P. J. Harrison unpubl.). Phagotrophic protists are the primary consumers of cells less than $5 \mu \mathrm{m}$ in size and can repackage them into biomass that can then be fed upon by larger planktonic organisms (Gifford 1991, Sanders \& Wickham 1993). The high abundances of such protists in coastal waters (Stoecker \& Capuzzo 1990) invite investigation into their role as a trophic link between microbial communities and invertebrate planktotrophic larvae.

·E-mail: sulkin@cc.wwu.edu
Zoeal larvae of most brachyuran crabs are planktotrophic, often requiring food soon after hatching to survive and develop normally (Anger \& Dawirs 1981, Staton \& Sulkin 1991, Hartman 1994). A growing body of evidence suggests that zoeae are encounter feeders, capable of consuming both living and non-living prey in sizes ranging from 10 to $250 \mu \mathrm{m}$ depending upon crab species (Costlow \& Bookhout 1959, Sulkin 1975 , Levine \& Sulkin 1984, Harms \& Seeger 1989, Lehto et al. 1998). A variety of autotrophic and heterotrophic protists have been tested in the laboratory as prey for crab larvae (Williams 1968, Sulkin 1975, Bigford 1978, Hartman \& Letterman 1978, Harms \& Seeger 1989. Lehto et al. 1998). Most studies indicate that brachyuran larvae consume protists and even detritus, but the nutritional gain from doing so varies considerably among prey and crab species. However, evaluation of the nutritional value of protistan prey is usually based on whether such prey can sustain larvae through the 
first zoeal stage to molting or, in some cases, all the way to metamorphosis. A more relevant criterion may be whether crab larvae can utilize protistan prey for even limited periods of time, given larval susceptibility to starvation and the likelihood that natural concentrations of optimal prey may be low or, at best, patchy (Harms \& Seeger 1989). This question may be especially relevant to newly hatched first stage brachyuran crab larvae that may be particularly susceptible to food deprivation.

The present study investigates the nutritional role played by 2 naturally occurring species of dinoflagellates, one autotrophic and one heterotrophic, in the first zoeal stage of the Dungeness crab Cancer magister. C. magister is a particularly interesting test species in that it releases its larvae in the waters of the Puget Sound (Washington, USA) basin in winter, a time of very low primary productivity (Copping 1982, Brainard 1996) and because it has been shown that the first zoeal stage can be sustained on a mixture of diatoms (Hartman \& Letterman 1978).

\section{METHODS}

Experimental approach. In a preliminary experiment, newly hatched larvae of Cancer magister were fed the heterotrophic dinoflagellate Oxyrrhis marina. The protist was cultured on an algal mixture of Isochrysis galbana, Pyrenomonas salina, and Dunaliella sp. Although crab larvae fed solely on the protist did not survive to the second zoeal stage, nor was mortality delayed as compared to unfed controls (Analysis of Variance, ANOVA: p > 0.05), dry weights of Day 5 larvae were higher than either Day 1 or Day 5 unfed larvae (ANOVA: $p<0.001$; Tukey's test for Paired Comparisons: $\mathrm{p}=0.05$ ).

This result suggested that reliance on the ability of protistan prey to sustain larvae to molting did not adequately describe their potential nutritional contributions. Accordingly, an experiment was designed in which 2 species of naturally occurring dinoflagellates were tested both singly and in combination with a suboptimal diet. The suboptimal diet is one in which a prey organism that is known to sustain development (Artemia sp. nauplii, in the present case) is manipulated such that larval survival is reduced and/or development is delayed as compared to its use in optimal applications (Levine \& Sulkin 1984). This suboptimal application can then be supplemented with the protist to determine whether the latter is contributing nutritionally. The specific treatment applications are described below.

Experimental crabs. Larvae were obtained for these experiments from a total of 4 ovigerous Cancer magis- ter, collected by SCUBA from Ship Harbor, WA, USA The ovigerous crabs were returned to the nearby Shannon Point Marine Center and placed individually in large tables fed by running seawater at ambient temperature and salinity $\left(7^{\circ} \mathrm{C}, 29 \mathrm{ppt}\right)$. Crabs were observed every second day for evidence of hatching and fed. When larvae were observed swimming in the seawater tables, the tank was drained, rinsed, and refilled at night so that freshly hatched larvae could be obtained early the next day. On the following day, several thousand larvae were collected from the seawater table in a large glass bowl. The bowl was gently agitated so as to maintain a homogeneous distribution of larvae. Larvae were selected haphazardly and placed individually into wells of a 12-well tray. Each well measured $25 \mathrm{~mm}$ in diameter and contained $5 \mathrm{ml}$ of filtered $(5 \mu \mathrm{m})$ seawater and 1 larva. A sufficient number of trays was set up so that 3 (36 larvae) could be assigned to each diet treatment to be tested in each experiment.

In Expt 1, 4 treatments were tested on larvae from each of 2 broods; thus, a total of 12 trays were set up for each brood. In Expt 2, 6 treatments were tested on larvae from 2 additional broods, requiring a total of 18 trays from each brood. In each experiment, trays of larvae from each brood were randomly distributed among the treatments to be tested. Larvae in each well tray were then fed the appropriate diet. The trays were initially filled with seawater at $7^{\circ} \mathrm{C}$ and placed into a light-temperature controlled incubator set at $12^{\circ} \mathrm{C}$, $10 \mathrm{~h}$ light: $14 \mathrm{~h}$ dark cycle. The water temperature was gradually increased to $12^{\circ} \mathrm{C}$ on the first day of culture and was thereafter maintained at that temperature.

Diet treatments. Following the general protocol for raising crab larvae in laboratory culture (Costlow et al. 1959, Williams 1968, Sulkin 1975), diets were provided daily in concentrations defined as 'in-excess;' that is, in sufficient quantities to assure that densities would not be limiting prior to the next addition of prey $24 \mathrm{~h}$ later Accordingly, prey densities were not defined during the experiment, although culture procedures promoted daily consistency of density of each prey organism used in the experiments.

In Expt 1, 2 experimental treatments were tested using diets consisting solely of either the autotrophic dinoflagellate Prorocentrum micans or the heterotrophic dinoflagellate Noctiluca scintillans (not bioluminescent in local populations). In addition, control treatments included an unfed group in which larvae were maintained in $5 \mu \mathrm{m}$ filtered seawater with no particulate food added and a group fed daily on freshly hatched nauplii of the brine shrimp Artemia sp. provided in excess. The 2 species of dinoflagellates were chosen because they are present in local waters and offer contrast in trophic level and size, the autotroph 
being 50 to $70 \mu \mathrm{m}$ in diameter and the heterotroph being 300 to $400 \mu \mathrm{m}$ in diameter. Furthermore, N. scintillans was cultured in the laboratory using $P$. micans as its prey.

In Expt 2, these same 2 protists were tested, along with the green alga Dunaliella tertiolecta (10 $\mu \mathrm{m}$ diameter), in combination with the Artemia sp. diet provided in suboptimal application. Based on the results of Sulkin et al. (1998), the suboptimal application of Artemia sp. involved a cycle of continuous feeding on Artemia sp. naupii for $24 \mathrm{~h}$, followed by $48 \mathrm{~h}$ of starvation. In the experimental treatments using each of the 3 protists, the diet consisted of the suboptimal application of Artemia sp. nauplii for $24 \mathrm{~h}$, followed by $48 \mathrm{~h}$ of the protist. Additional treatments (controls) included an unfed group and a group fed daily on in-excess rations of Artemia sp. nauplii.

Protist culture procedures. Culture procedures for the 3 protists are described in Lehto et al. (1998). Briefly, Noctiluca scintillans was cultured in $4 \mathrm{l}$ polycarbonate bottles containing $0.2 \mu \mathrm{m}$ filtered and autoclaved seawater. The cultures were fed Prorocentrum micans and were incubated at $12^{\circ} \mathrm{C}$ in dim light. $N$. scintillans cells were concentrated for use as a diet for crab larvae by reverse filtration ( $80 \mu \mathrm{m}$ mesh) so as to provide a density sufficient for in-excess application daily. P. micans and Dunaliella tertiolecta were cultured separately in $1 \mathrm{l}$ polycarbonate bottles in $\mathrm{f} / 2$ medium. The cultures were maintained at $22^{\circ} \mathrm{C}$ on a $12 \mathrm{~h}$ light: $12 \mathrm{~h}$ dark cycle. Artemia sp. nauplii were hatched daily for use as described in Sulkin \& McKeen (1989).

Larval culture procedures. Larvae in each tray were examined daily for evidence of mortality and molting, transferred to new well trays containing filtered $(5 \mu \mathrm{m})$ seawater (29 ppt), and fed the apprapriate diet. All trays were maintained at $12^{\circ} \mathrm{C}$ on a $10 \mathrm{~h}$ light: $14 \mathrm{~h}$ dark cycle. Cultures were maintained until all larvae had either died or molted to zoeal stage II.

\section{RESULTS}

In Expt 1, larvae fed Artemia sp. nauplii in excess showed $83 \%$ survival to zoeal stage II (mean day of molt: $11.2 \pm 1.1$ ), while unfed larvae experienced $100 \%$ mortality by Day 9 (Fig. 1). However, although larvae fed solely on either Noctiluca scintillans or Prorocentrum micans did not survive to zoeal stage II, larvae fed both prey showed a delay in mortality as compared to unfed larvae (Fig. 1). This observation was tested further by comparing days of death among the 3 treatments. A Bartlett's test of equal variances was significant $(p<0.05)$, requiring the use of the non-parametric Kruskal-Wallis ANOVA (significant at $\mathrm{p}<0.001$ ).

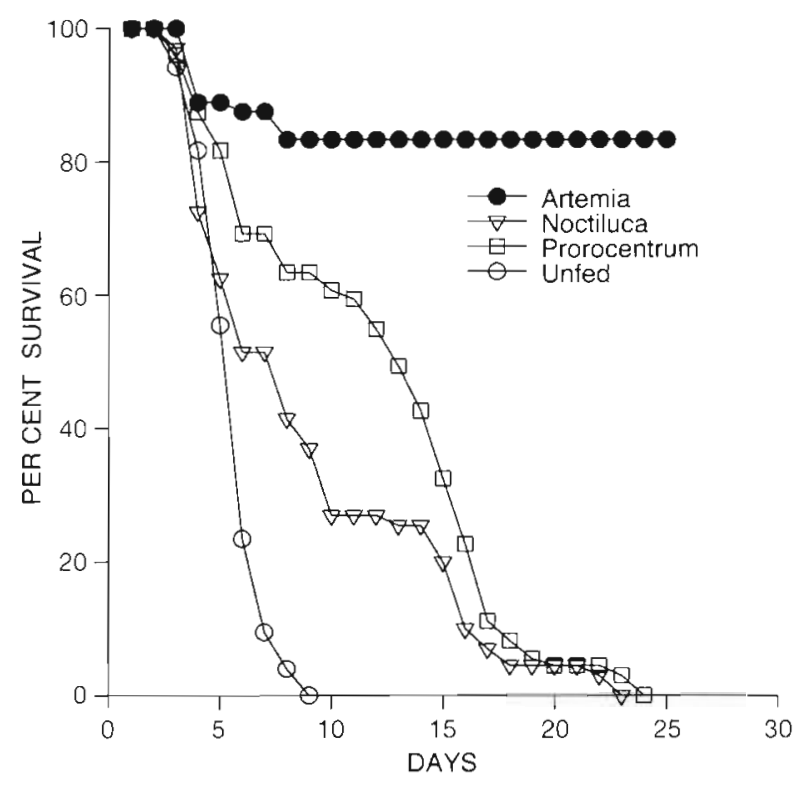

Fig. 1. Cancer magister. Daily survival of stage 1 larvae fed the indicated diets. Mean day of molt for Artemia sp. treatment $11.2 \pm 1.1$

Treatments were compared against one another using a Comparison of Mean Ranks test ( $p=0.05)$, the results indicating that larvae fed both species of dinoflagellates experienced delayed mortality as compared to unfed larvae (Table 1). P. micans-fed larvae survived longer than did those fed $N$. scintillans (Table 1). It is apparent that larvae were consuming both dinoflagellates and deriving some nutritional benefit from them, but neither alone provided sufficient nutrition to sustain larvae through the first zoeal stage.

In Expt 2, both species of dinoflagellates and the green alga Dunaliella tertiolecta supported development to the second zoeal stage when fed in combination with the suboptimal Artemia sp. nauplii diet (Fig. 2). In this experiment, unfed larvae showed 100\% mortality by Day 7 (Fig. 2). A comparison among treatments of percent survival to zoeal stage II (ANOVA on arc sine transformed data) indicated significant differ-

Table 1. Cancer magister. Mean days of death (standard error) for larvae fed the indicated diets $\mathrm{n}$ : number of larvae included in each treatment. Results of a Comparison of Mean Ranks (CMR) test are shown; shared letters indicate no significant difference among samples $(p=0.05)$

\begin{tabular}{|lccc|}
\hline Diet treatment & $\begin{array}{c}\text { Mean day } \\
\text { of death }\end{array}$ & $\mathrm{n}$ & $\mathrm{CMR}$ \\
\hline Prorocentrum micans & $12.2(0.72)$ & 71 & $\mathrm{a}$ \\
Noctiluca milaris & $9.0(0.65)$ & 71 & $\mathrm{~b}$ \\
Unfed & $5.7(0.17)$ & 72 & $\mathrm{c}$ \\
\hline
\end{tabular}




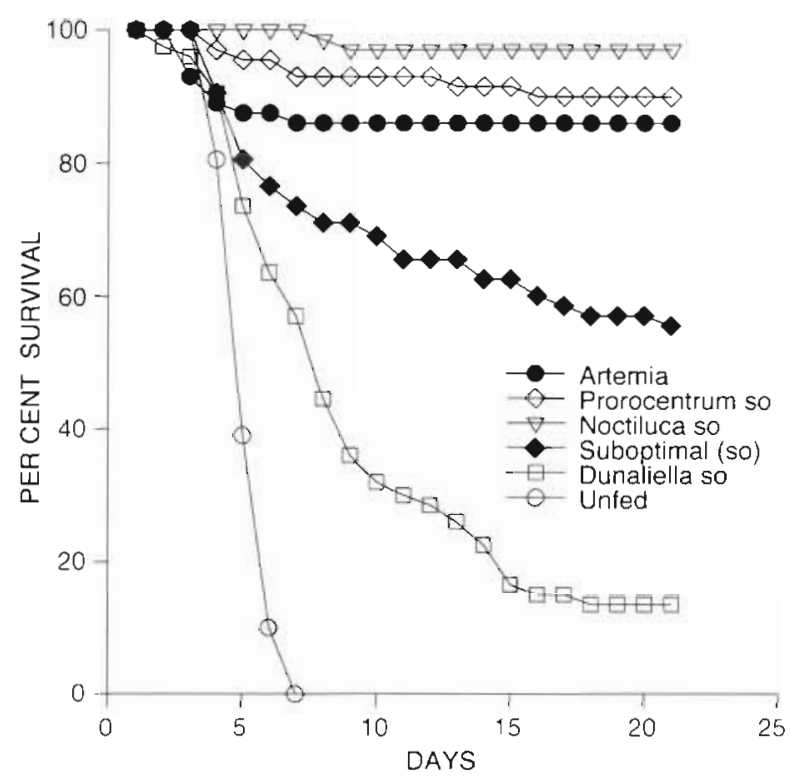

Fig. 2. Cancer magister. Daily survival of stage 1 larvae fed the indicated diets. Suboptimal (SO) diet described in text.

Mean days of molt for each treatment shown in Table 3

ences $(p<0.001)$. The results of a Tukey's Honestly Significant Difference (HSD) test $(p=0.05)$ indicated that survival was the same among larvae fed the 2 dinoflagellates (in combination with the suboptimal diet) and the control diet of Artemia sp. nauplii, with all 3 showing higher survival than for larvae fed the suboptimal diet alone (Table 2). Direct observations indicated that larvae do consume individual $D$. tertiolecta cells, an observation confirmed by an experiment in which mean day of death of $D$. tertiolecta-fed larvae exceeded that of unfed siblings ( $\mathrm{n}=12$; Wilcoxon Signed Rank test: $p<0.05$ ). However, larvae fed $D$. tertiolecta in combination with the suboptimal diet showed significantly lower survival to zoeal stage II than was the case for larvae fed the suboptimal diet alone (Table 2). Results indicate that larvae were feeding on all 3 protists deriving significant nutritional benefit from the 2 dinoflagellates, but not from the green alga. Indeed, the green algal diet actually reduced larval survival.

Duration of zoeal stage I was compared among treatments using mean days of molt to stage II (Table 3). The Bartlett's equal variance test was significant ( $p<$ 0.05), requiring use of the Kruskal-Wallis non-parametric ANOVA (significant at $p<0.001)$. The CMR test $(p=0.05)$ indicated that larvae fed the suboptimal diet took significantly longer to develop to stage II than did Artemia-fed larvae. Addition of Dunaliella tertiolecta to the suboptimal diet had no effect; however, addition of either of the 2 dinoflagellate species significantly accelerated development as compared to the suboptimal diet alone. Nonetheless, neither dinoflagellate in combination with the suboptimal diet accelerated development sufficiently to equal the duration of Artemia-fed larvae.

\section{DISCUSSION}

Lehto et al. (1998) have shown that larvae of the crab Hemigrapsus oregonensis, also found in waters of the Puget Sound basin, can feed on both species of dinoflagellate tested in the present study, as well as on microbially colonized detrital particles. We demonstrate here that the hatching stage of Cancer magister also can utilize the dinoflagellates Prorocentrum micans and Noctiluca scintillans

Although neither species of dinoflagellate, by itself, sustained survival of stage I Cancer magister larvae, both clearly were being consumed and were contributing nutritionally. Sulkin et al. (1998) have reported that C. magister larvae do not need continuous access to

Table 2. Cancer magister. Mean percent survival (standard error) to zoeal stage II for larvae fed the indicated diets. Suboptimal diet described in text. $n$ : number of experimental replicates. Results of a Tukey's HSD test shown; shared letters indicate no significant difference $(p=0.05)$

\begin{tabular}{|lccc|}
\hline Diet treatment & $\begin{array}{c}\text { Percent } \\
\text { survival }\end{array}$ & n & $\begin{array}{c}\text { Tukey's } \\
\text { HSD }\end{array}$ \\
\hline Noctiluca scintillans suboptinal & $96.8(1.95)$ & 5 & $\mathrm{a}$ \\
Prorocentrum micans suboptimal & $90.3(4.00)$ & 6 & $\mathrm{a}$ \\
Axtemia sp. & $86.2(2.86)$ & 6 & $\mathrm{a}$ \\
Suboptimal & $53.2(8.90)$ & 6 & $\mathrm{~b}$ \\
Dunaliella tertiolecta suboptimal & $11.1(4.15)$ & 6 & $\mathrm{c}$ \\
Unfed & 0 & 6 & - \\
\hline
\end{tabular}

Table 3. Cancer magister. Mean day of molt (SE) to zoeal stage II for larvae fed the indicated diets. Suboptimal diet described in text. n: number of larvae included in each treatment. Results of a Comparison of Mean Ranks (CMR) test is shown; shared letters indicate no significant difference among samples $(p=0.05)$

\begin{tabular}{|lccc|}
\hline Diet treatment & $\begin{array}{c}\text { Mean day } \\
\text { of molt }\end{array}$ & $\mathrm{n}$ & $\mathrm{CMR}$ \\
\hline Artemia sp. & $9.5(0.14)$ & 62 & $\mathrm{a}$ \\
Prorocentrum micans suboptimal & $11.2(0.19)$ & 64 & $\mathrm{~b}$ \\
Noctiluca scintillans suboptimal & $12.1(0.15)$ & 58 & $\mathrm{~b}$ \\
Dunaliella tertiolecta suboptimal & $18.8(0.52)$ & 9 & $\mathrm{c}$ \\
Suboptimal & $18.8(0.25)$ & 37 & $\mathrm{c}$ \\
\hline
\end{tabular}


high quality prey to survive and develop normally. The present results indicate that larval survival can be enhanced when occasional access to high quality food (Artemia sp. nauplii) is supplemented with consumption of 2 types of dinoflagellates. Indeed, survival of the first larval stage was equal to the fed control when larvae were fed either dinoflagellate for as much as 2 out of every $3 d$, as long as larvae were fed the control diet on the third day. It is important to note, moreover, that the 2 species of dinoflagllates used in this study were isolated from local waters where newly hatched $C$. magister larvae are released. Given the susceptibility of newly hatched brachyuran larvae to starvation (Anger \& Dawirs 1981, Staton \& Sulkin 1991, Hartman 1994) and the likelihood of their encountering low concentrations of micro-crustaceans and other small animal prey on a continuous basis in their natural habitat (Incze \& Paul 1983, Paul et al. 1989), their ability to obtain nutrition from protists as prey may be significant. Indeed, C. magister larvae hatch in late winter in the waters of the northern Puget Sound basin, a time of low primary productivity (Copping 1982, Brainard 1996). Moreover, egg-bearing females spend the winter buried in the mud in seagrass beds (Armstrong et al. 1987. Sulkin pers. obs.), an adaptation thought to provide protection to the adults (Thayer \& Phillips 1977). However, this habit also will result in the release of newly hatched larvae into an environment potentially rich in the carbon sources of the microbial food web.

Seagrass beds are known to harbor high concentrations of detritus, both because death and decomposition is the primary fate of seagrass biomass (Klumpp et al. 1989) and because seagrass beds attentuate wind and tidal mixing energy, promoting deposition of suspended particulates (Ward et al. 1984, Worcester 1995). Indeed, Thresher et al (1992) concluded that seagrass detritus was the basis of a microbial food web in Tasmanian coastal waters that supported large protists and, ultimately, larval fish. Smith \& Hobson (1994) concluded that a food web composed of heterotrophic protists consuming particulate debris, as well as bacterial and algal cells, dominated the winter ecology of an inlet in the Puget Sound basin. Immediate access to an abundant and predictable source of such nutrition in the waters above the seagrass beds where they hatch may be important for Cancer magister larvae released during a season of low primary productivity.

Our results demonstrate that not all protists provide nutritional benefit. Indeed, consumption of the green alga Dunaliella tertiolecta actually reduced survival. The very low omega-3 polyunsaturated fatty acid content of $D$. tertiolecta may contribute to the low quality of this algal diet (Volkman et al. 1989, Hartman 1994), an hypothesis consistent with the reports of Levine \&
Sulkin (1984) that crab larvae require a dietary source of such fatty acids. However, reduced fatty acid availability does not, in itself, explain the observed reduction in survival relative to suboptimal controls, a result that will require further study. Our experiments do not preclude the possibility, for example, that exudates produced in the algal cultures may have had a deleterious effect upon the crab larvae. Nevertheless, our results suggest that unless crab larvae feed selectively when they encounter a mix of protistan species, the net effect of protist consumption may be hard to predict and may differ considerably among crab species.

Although both dinoflagellates supported survival to Stage II equal to that of the Artemia sp. control, development was delayed in both cases. Thus, larvae whose survival is dependent upon supplementing optimal prey with protists early in their development may experience the consequences associated with a prolonged planktonic stage, including increased mortality due to predation and possible changes in growth due to the extended period of satisfying metabolic requirements in an uncertain prey field.

Although the ultimate consequences to larval survival and growth that can be attributed to feeding on protists remain to be determined, our results indicate that crab larvae can consume and derive nutrition from both autotrophic and heterotrophic protists. Although such protistan diets may not be sufficient to sustain development, they may be important as a supplemental nutrition source when other prey are not available, particularly when larvae first hatch. In this role, they may comprise a link between the rich carbon sources of the microbial food web and metazoans.

Acknowledgements. This manuscript includes data submitted in partial fulfillment of the Master of Science degree to Western Washington University by the second author This research was supported in part by a grant from the Washington Sea Grant Program. The second author was supported by grants from the Padilla Bay Foundation, the Padilla Bay National Estuarine Research Reserve and the Shell Oil Company. The fourth author was supported by NSF grant OCE- 9315422 (Minorities in Marine Science Undergraduate Program).

\section{LITERATURE CITED}

Anger K, Dawirs RR (1981) The influence of starvation on the larval development of Hyas areneus (Decapoda: Majidae). Helgol Wiss Meeresunters 34:287-311

Armstrong DA, Armstrong JL, Dinnel PA (1987) Ecology and population dynamics of Dungeness crab, Cancer magister, in Ship Harbor, Anacortes, Washington. Final Report to Leeward Development Co. and Wash. Dept. Fish. FRIUW-8701, Olympia, WA

Bigford TE (1978) Effect of several diets on survival, development time, and growth of laboratory reared spider crab, Libinia emarginata, larvae. Fish Bull US 76:59-64

Brainard MA (1996) Seasonal phytoplankton growth and 
microzooplankton grazing in North Puget Sound, Washington. MS thesis, Western Washington University, Bellingham, WA

Copping AE (1982) The distribution and passage of organic matter in the marine food web, using nitrogen as a tracer. PhD thesis, University of Washington, Seattle, WA

Costlow JD Jr, Rees G, Bookhout CG (1959) Preliminary notes on the complete larval development of Callinectes sapidus Rathbun under laboratory conditions. Limnol Oceanogr 4 : $222-223$

Gifford DJ (1991) The protozoan-metazoan trophic link in pelagic ecosystems. J Protozool 38:81-86

Harms J, Seeger B (1989) Larval development and survival in seven decapod species (Crustacea) in relation to laboratory diet. J Exp Mar Biol Ecol 133:129-139

Hartman M (1994) Effect of exposure of ovigers to petroleum hydrocarbon on subsequent zoeal development of the brachyuran crab Hemigrapsus oregonensis using diet as an experimental tool. MS thesis, Huxley College of Environmental Science, Western Washington University, Bellingham, WA

Hartman M, Letterman G (1978) An evaluation of three species of diatoms as food for Cancer magister larvae. In Avault J (ed) Proc Ninth Annual Meeting, World Mariculture Soc J, p 271-276

Incze LS, Paul AJ (1983) Grazing and predation as related to energy needs of stage I zoeae of the tanner crab Chionoecetes bairdi (Brachyura, Majidae). Biol Bull (Woods Hole) 165:197-208

Joint IR, Pomroy AJ (1983) Production of picoplankton and nanoplankton in the Celtic Sea. Mar Biol 77:19-27

Klumpp DW, Howard RK, Pollard DA (1989) Trophodynamics and nutritional ecology of seagrass communities. In Larkum AWD, McComb AJ, Shepard SA (eds) Biology of seagrasses. Elsevier, Amsterdam, p 394-457

Lehto J, Sulkin S, Strom S, Johnson D (1998) Protists and detrital particles as prey for the first larval stage of the brachyuran crab, Hemigrapsus oregonensis. J Exp Mar Biol Ecol (in press)

Levine D, Sulkin SD (1984) Nutritional significance of longchain polyunsaturated fatty acids to the zoeal development of the brachyuran crab Eurypanopeus depressus Smith. J Exp Mar Biol Ecol 81:221-223

Paul AJ, Paul JM, Coyle KO (1989) Energy sources for firstfeeding zoeae of king crab Paralithodes camtschatica (Tilesius) (Decapoda, Lithodidae). J Exp Mar Biol Ecol 130:55-69

Editorial responsibility: Jennifer Purcell /Contributing Editor), Cambridge, Maryland, USA
Sanders RW, Wickham SA (1993) Planktonic protozoa and metazoa: predation, food quality and population control. Mar Microb Food Webs 7:197-223

Sherr EB, Sherr BF (1991) Planktonic microbes: tiny cells at the base of the ocean's food web. Trends Ecol Evol 6: $50-54$

Smith PJ, Hobson LA (1994) Temporal variations in the taxonomic composition of flagellated nanoplankton in a temperate fjord. J Phycol 30:369-375

Staton JL, Sulkin SD (1991) Nutritional requirements and starvation resistance in larvae of the brachyuran crabs Sesarma cinereum (Bosc) and S. reticulatum (Say). J Exp Mar Biol Ecol 152:271-284

Stoecker DK, Capuzzo JM (1990) Predation on protozoa: its importance to zooplankton. J Plankton Res 12:891-908

Sulkin SD (1975) The significance of diet in the growth and development of larvae of the blue crab, Callinectes sapidus, under laboratory conditions. J Exp Mar Biol Ecol 20:119-135

Sulkin SD, Blanco A, Chan J, Bryant M (1998) The effects of limiting access to prey on the development of the first zoeal stage of the brachyuran crabs Cancer magister and Hemigrapsus oregonensis. Mar Biol (in press)

Sulkin SD, Mckeen GL (1989) Laboratory study of survival and duration of individual zoeal stages as a function of temperature in the brachyuran crab Cancer magister. Mar Biol 103:31-37

Thayer GW, Phillips RC (1977) Importance of eelgrass beds in Puget Sound. Mar Fish Rev 1271:18-22

Thresher RE, Nichols PD, Gunn JS, Bruce BD, Furlani DM (1992) Seagrass detritus as the basis of a coastal planktonic food chain. Limnol Oceanogr 37:1754-1758

Throndsen J (1979) Productivity and abundance of ultra- and nano-plankton in Oslofjorden. Sarsia 63:273-284

Volkman JK, Jeffrey SW, Nichols PD, Rogers GI, Garland CD (1989) Fatty acid and lipid composition of 10 species of microalgae used in mariculture. J Exp Mar Biol Ecol 128: $219-240$

Ward LG, Kemp WM, Boynton WR (1984) The influence of waves and seagrass communities on suspended particulates in an estuarine embayment. Mar Geol 59:85-103

Williams BG (1968) Laboratory rearing of the larval stages of Carcinus maenas. J Nat Hist 2:121-126

Worcester SE (1995) Effects of eelgrass beds on advection and turbulent mixing in low current and low shoot density environments. Mar Ecol Prog Ser 126:223-232

Submitted: December 1, 1997; Accepted: May 15, 1998

Proofs received from author(s): July 20, 1998 